\title{
Phenotypic expression of the fibroblast growth factor receptor 3 (FGFR3) mutation P250R in a large craniosynostosis family
}

Astrid Golla, Peter Lichtner, Steven von Gernet, Andreas Winterpacht, Jeffrey Fairley, Jan Murken, Simone Schuffenhauer

\begin{abstract}
The craniosynostosis syndromes are a heterogeneous group of sporadic, autosomal dominant disorders with significant clinical overlap. Recently, we described a large family with autosomal dominant craniosynostosis suggestive of SaethreChotzen syndrome, in which linkage to the Saethre-Chotzen syndrome loci on $7 p$ had been excluded.

We now report the presence of a mutation in the fibroblast growth factor receptor 3 (FGFR3) in this family. The mutation, P250R, had been previously reported in 10 patients with non-syndromic craniosynostosis. Variable expression of this mutation is evident especially in two additional members of this family, one of whom is severely affected with pancraniosynostosis. The family provides a further example of genetic heterogeneity and variable expression of the craniosynostosis syndromes and broadens the phenotypic spectrum associated with the FGFR3 mutation P250R. In addition, we found a polymorphism (F384L) in the transmembrane domain of FGFR3 which occurs with a frequency of $3 \%$ in the Turkish population but is uncommon among Germans.

$(\mathcal{H}$ Med Genet 1997;34:683-684)
\end{abstract}

Keywords: craniosynostosis; Saethre-Chotzen syndrome; FGFR3
The craniosynostosis syndromes are characterised by marked genetic and allelic heterogeneity. Mutations in two out of four known fibroblast growth factor receptor (FGFR) genes account for various forms of craniosynostosis, such as Crouzon, Apert, Jackson-Weiss (FGFR2), and Pfeiffer (FGFR1, FGFR2) syndromes. $^{1-7}$ Recently, a single recurrent mutation in the FGFR3 gene, P250R, was reported to cause non-syndromic craniosynostosis. $^{8}$ FGFR3 was previously shown to be mutated in various forms of dwarfism $^{9-11}$ and Crouzon syndrome with acanthosis nigricans. ${ }^{12}$

Here we report the presence of the mutation $P 250 R$ in FGFR3 in a large German family (family 1) (fig 1) with craniosynostosis and additional features suggestive of SaethreChotzen syndrome. The phenotype of eight affected subjects has been described previously. ${ }^{13}$ They show unilateral $(4 / 8)$ or bilateral $(4 / 8)$ coronal synostosis of varying degree and a low frontal hairline (8/8). Other features include hypertelorism (7/8), facial asymmetry (5/8), strabismus ( $3 / 8)$, ptosis $(2 / 8)$, partial cutaneous syndactyly $(3 / 8)$, and brachydactyly (1/8). Characteristics of other craniosynostosis syndromes, such as midface hypoplasia, osseous syndactylies, and broad big toes and thumbs were absent. In the meantime two further affected family members were born. Subject IV.9 presents with unilateral coronal synostosis, marked facial asymmetry,

A Golla

P Lichtner

J Murken

S Schuffenhauer

\section{Abteilung für \\ Plastische Chirurgie, Städtisches \\ Krankenhaus \\ Bogenhausen, München, Germany \\ $S$ von Gernet \\ J Fairley \\ Kinderklinik und Kinderpoliklinik, Johannes \\ Gutenberg-Universität Mainz, Mainz, Germany \\ A Winterpacht \\ Correspondence to: Dr Golla.}

Received 14 November 1996 Revised version accepted for publication 3 March 1997

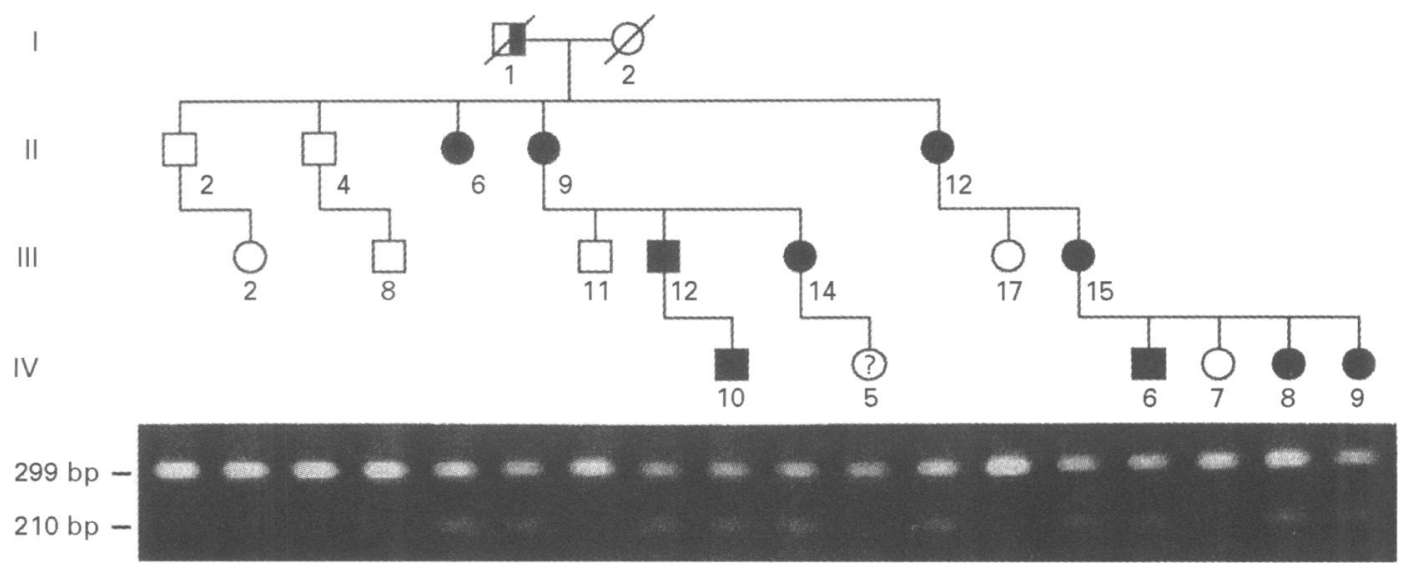

Figure 1 Pedigree of family 1 and segregation pattern of the C749G (P250R) mutation. The mutation creates a BanI restriction site, generating 210 and 89 bp fragments in addition to the normal (uncleaved) 299 bp amplification product of exon 7. For amplification of exon 7 of FGFR3 the following primers were designed using intronic sequences: $5^{\prime} C G G C A G$ TGG CGG TGG TGG TG 3' and 5' CCA GCC CAG GAG CCC CAG CG 3'. Family members are numbered according to a previous report. ${ }^{13}$ 


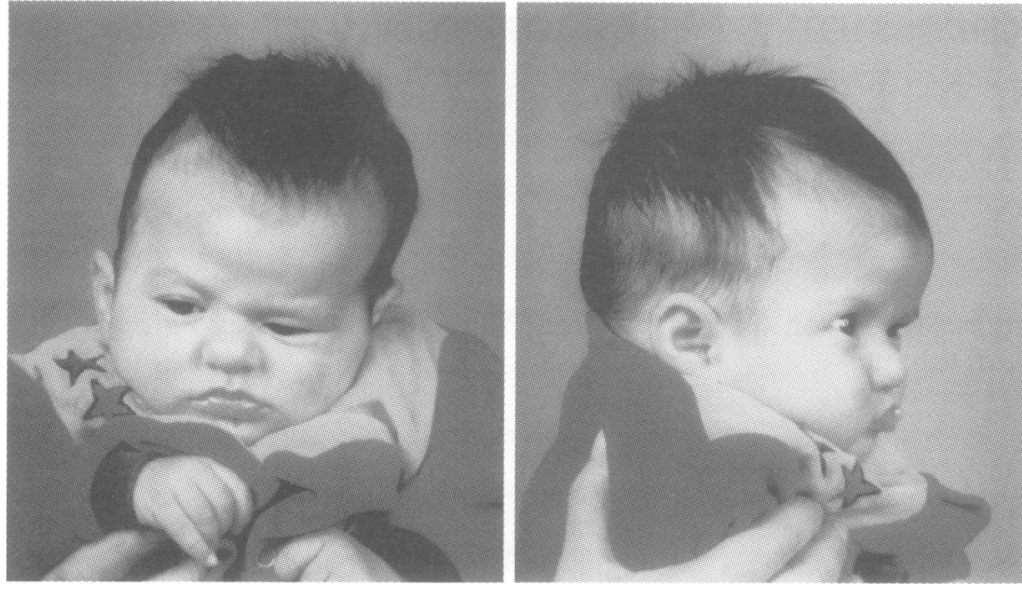

Figure 2 Affected subject IV.9 (family 1) with unilateral coronal craniosynostosis at the age of 3 months. Note marked facial asymmetry and domed forehead with relatively low frontal hairline.

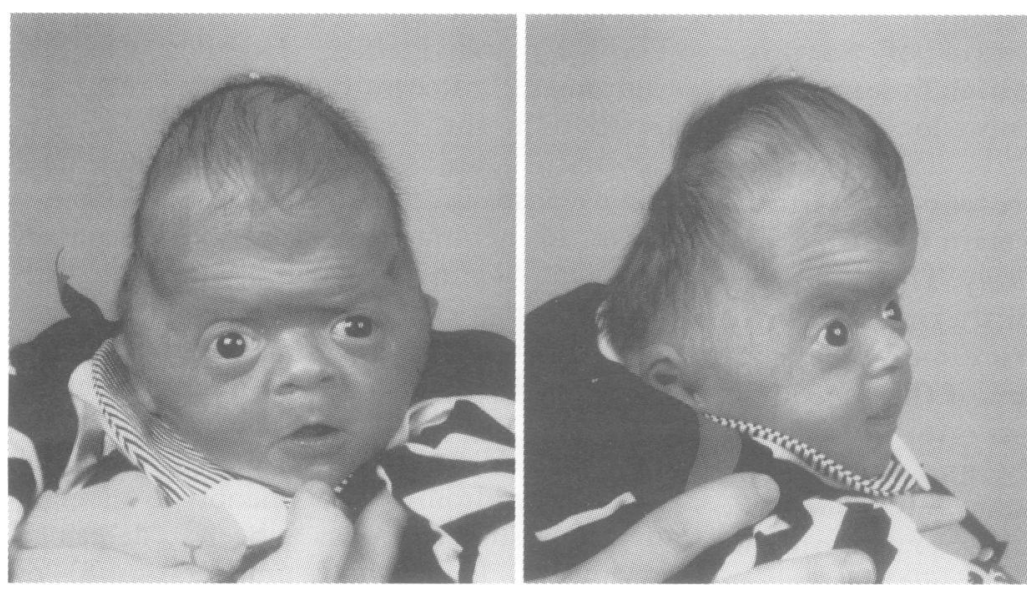

Figure 3 Affected subject IV.10 (family 1) with pancraniosynostosis at the age of 1 week. Note "cloverleaf skull", proptosis, downward slanting palpebral fissures, and low set ears.

and deviation of the nasal septum (fig 2), like her affected sibs. Subject IV.10 (fig 3 ) is severely affected with pancraniosynostosis, ocular proptosis, and downward slanting palpebral fissures. The "cloverleaf skull" was detected prenatally by ultrasound in the 30th week of gestation. Both IV.9 and IV.10 have normal hands and feet.

Using linkage analysis we mapped the disease locus to a $30 \mathrm{cM}$ interval on $4 \mathrm{p} 16$ which includes the FGFR3 gene. Mutation analysis using SSCP of the transmembrane domain (for primers see Shiang $e t a l^{p}$ ) showed a TC transition at nucleotide position 1150 of FGFR3 in the affected subject IV.6, his unaffected sister IV.7, and the unaffected father, who is of Turkish descent. T1150C predicts the amino acid exchange F384L and creates a $M n l I$ restriction site. $M n l I$ restriction digest in 50 healthy subjects each of German and Turkish descent showed the heterozygous presence of F384L in three out of the 50 Turkish controls but none of the Germans. F384L lies between the common achondroplasia mutation (G380R) and the recurrent mutation in Crouzon syndrome with acanthosis nigri- cans (A391E). The altered amino acid sequence maintains the hydrophobicity in the transmembrane domain and is present in the bovine FGFR3 homologue, which points to a normal function (BLASTA and BLASTN search $^{14}$ : blast@ncbi.nlm.nih.gov).

Restriction enzyme digest (BanI) of an exon 7 PCR product of FGFR3 showed P250R to be the causative mutation in the family. The mutation segregates completely with the phenotype, pointing to full penetrance (fig 1). Subject IV.10 with pancraniosynostosis thus represents the most severely affected patient not only in family 1 , but also in respect to the patients described so far with mutation P250R. ${ }^{8}$

P250R was also found in a girl and her mother (family 2) with unilateral coronal synostosis and mild brachydactyly. It was absent in six sporadic patients with various forms of craniosynostosis.

On the basis of the broad clinical spectrum in family 1 and the relatively high prevalence of P250R in craniosynostosis patients ${ }^{8}$ (this study), we suggest that analysis of this mutation is an important tool for diagnosis and genetic counselling of patients with various forms of isolated and syndromic craniosynostosis.

We thank the family for their participation, and Thomas Meitinger (Munich) and Maximilian Muenke (Philadelphia) for support.

1 Schell U, Hehr A, Feldman GJ, et al. Mutations in FGFR1 and FGFR2 cause familial and sporadic Pfeiffer syndrome. Hum Mol Genet 1995;4:323-8.

2 Muenke M, Schell U, Hehr A, et al. A common mutation in the fibroblast growth factor receptor 1 gene in Pfeiffer syndrome. Nat Genet 1994;8:269-74.

3 Jabs EW, Li X, Scott AF, et al. Jackson-Weiss and Crouzon syndromes are allelic with mutations in fibroblast growth factor receptor 2. Nat Genet 1994;8:98-103.

4 Reardon W, Winter RM, Rutland P, Pulleyn LJ, Jones BM, Malcolm S. Mutations in the fibroblast growth factor receptor 2 gene cause Crouzon syndrome. Nat Genet 1994; receptor 2 .

5 Wilkie AOM, Slaney SF, Oldridge M, et al. Apert syndrome results from localized mutations of FGFR2 and is allelic results from localized mutations of FGFR2 and is
with Crouzon syndrome. Nat Genet 1995;9:165-72.

6 Lajeunie E, Ma HW, Bonaventure J, Munnich A, Le Merrer M. FGFR2 mutations in Pfeiffer syndrome. Nat Genet 1995;9:108.

7 Rutland P, Pulleyn LJ, Reardon W, et al. Identical mutations in the FGFR2 gene cause both Pfeiffer and Crouzon syndrome phenotypes. Nat Genet 1995;9:173-6.

8 Bellus GA, Gaudenz K, Zackai EH, et al. Identical mutations in three different fibroblast growth factor receptor genes in autosomal dominant craniosynostosis syndromes. Nat Genet 1996;14:174-6.

9 Shiang A, Thompson L, Zhu YZ, et al. Mutations in the transmembrane domain of FGFR3 cause the most common genetic form of dwarfism, achondroplasia. Cell 1994;78:335-42.

10 Bellus GA, McIntosh I, Smith EA, et al. A recurrent mutation in the tyrosine kinase domain of fibroblast growth factor receptor 3 causes hypochondroplasia. Nat Genet 1995; tor recept

11 Tavormina PL, Shiang R, Thompson LM, et al. Thanatophoric dysplasia (types I and II) caused by distinct
mutations in the fibroblast growth factor receptor 3. Nat mutations in the fib

12 Meyers GA, Orlow SJ, Munro IR, Przylepa KA, Jabs EW. Fibroblast growth factor receptor 3 (FGFR3) transmembrane mutation in Crouzon syndrome with acanthosis nigricans. Nat Genet 1995;11:462-4

13 von Gernet S, Schuffenhauer S, Golla A, et al. Craniosynostosis suggestive of Saethre-Chotzen syndrome: clinical description of a large kindred and exclusion of candidate regions on 7p. Am F Med Genet 1996;63:177-84.

14 Altschul SF, Gish W, Miller W, Myers EW, Lipman D. Basic local alignment search tool. F Mol Biol 1990;215:403-10. 